\title{
The Carbon Footprint of Alexandria Governorate, Egypt and its contribution to climate change
}

\author{
Khaled Mohamed Madkour Ali ${ }^{1}$.
}

\begin{abstract}
:
The carbon footprint is a term used to describe the total amount of carbon dioxide $\mathrm{CO}_{2}$ and other greenhouse gases GHG's emissions for which an individual or organization is responsible.

The main objective of this study is to calculate the carbon footprint (CFP) in Alexandria governorate. This study relies on calculating emissions of GHG's from the major energy consumptions (Electricity, Natural Gas, Diesel, and Gasoline) and Waste in the area under investigation, which ran from 2010 through 2015. In addition to determining the contribution of Alexandria governorate to climate change and its share of the volume of GHG's emissions in Egypt.

This study concluded that the total carbon footprint of Alexandria governorate is 8.9 m million ton $\mathrm{CO}_{2} \mathrm{e} /$ year. The electricity and petroleum consumptions contribute with about $93 \%$ of the total carbon footprint of Alexandria governorate. [Bul. Soc. Géog. d'Égypte, 2019, 92: 90-101].
\end{abstract}

Key Words: Carbon footprint; Alexandria governorate; Climate change

\section{Introduction:}

The World Resources Institute (WRI) describes the term of the carbon footprint as "a representation of the effect you, or your organization, have on climate change in terms of the total amount of Greenhouse Gases (GHG's) produced (measured in units of carbon dioxide $\mathrm{CO}_{2} \mathrm{e}$ ). A carbon footprint offers a mean to identify carbon emission sources and to evaluate progress in the reduction of these emissions (World Resources Institute, 2011). Carbon footprint is a widely accepted method of measuring the impact of human activity on climate change. Carbon footprints are commonly measured in metric tons of carbon dioxide equivalents $\left(\mathrm{MTCO}_{2} \mathrm{e}\right)(\mathrm{AUC}, 2011)$.

This study focuses exclusively on Alexandria governorate, Egypt. and aims at making Greenhouse Gasses (GHGs) inventory and mitigation. This study relies on calculating emissions of GHGs from the major consumption activities (Electricity, Natural Gas, Diesel, and Gasoline) and Waste in the area under investigation, which ran from 2010 through 2015. In addition to determining the contribution of Alexandria governorate to climate change and its share of the volume of GHG's emissions in Egypt. Indisputably, the importance of cities in the search for effective climate change mitigation strategies is high, as cities have been estimated to produce up to $80 \%$ of global greenhouse gases (GHGs). (United Nations: New York, USA, 2007).

\footnotetext{
${ }^{1}$ Dr. khaled Mohamed Madkour Ali.

Lecturer, Department of Geography, Faculty of Arts, Ain Shams University, Cairo, Egypt.

e-mail: Khaled.madkour@art.asu.edu.eg
} 


\section{Study area:}

Alexandria governorate lies in the north coast of Egypt, it has the second largest metropolitan in Egypt (figure 1), and it is one of the major cities on the Mediterranean region with a total population estimated at $5.3 \mathrm{Ma}$ and a population density of $3044 / \mathrm{km}^{2}$, it accounts for about $5.5 \%$ of Egypt population (CAMPAS, 2018). It has the largest harbor in the country serving about $60 \%$ of Egypt's imports and exports (Alexandria Port Authority, 2018), and about $30 \%$ of Egypt's industrial activities (Alexandria governorate, 2018).

\section{Methodology:}

Generally, carbon emissions are calculating using methodologies and default values suggested by the IPCC. These estimates include sectoral estimations, which based on a detailed sectoral analysis. Many carbon footprint calculations are based on household or individual consumption behavior with a view to influencing changes in behavior toward a more energy efficient lifestyle. Alexandria governorate emission calculations are premised on the methodology provided by the Intergovernmental Panel on Climate Change (IPCC), the GHG Protocol Initiative and the Climate Registry.

This study accounts for three of the six main greenhouse gases (GHGs): Carbon Dioxide $\left(\mathrm{CO}_{2}\right)$, Methane $(\mathrm{CH} 4)$ and Nitrous Oxide $\left(\mathrm{N}_{2} \mathrm{O}\right)$. The main unit of measure is metric tons (MT) of carbon dioxide equivalents $\left(\mathrm{CO}_{2} \mathrm{e}\right)$ (Calabrese, 2010 \& World Bank, 2011). Carbon dioxide equivalents of $\mathrm{CH} 4$ and $\mathrm{N}_{2} \mathrm{O}$ are based on the global warming potential (GWP) of each gas which compares the amount of heat trapped by a similar mass of carbon dioxide. Methane has a GWP of 21 and nitrous oxide has a GWP of 310 over a 100-year interval (Global Warming Potentials, 2011). Carbon dioxide equivalents $\left(\mathrm{CO}_{2} \mathrm{e}\right)$ are used here to express the relative global warming impact of each of the three greenhouse gases through a single unit of measure. 


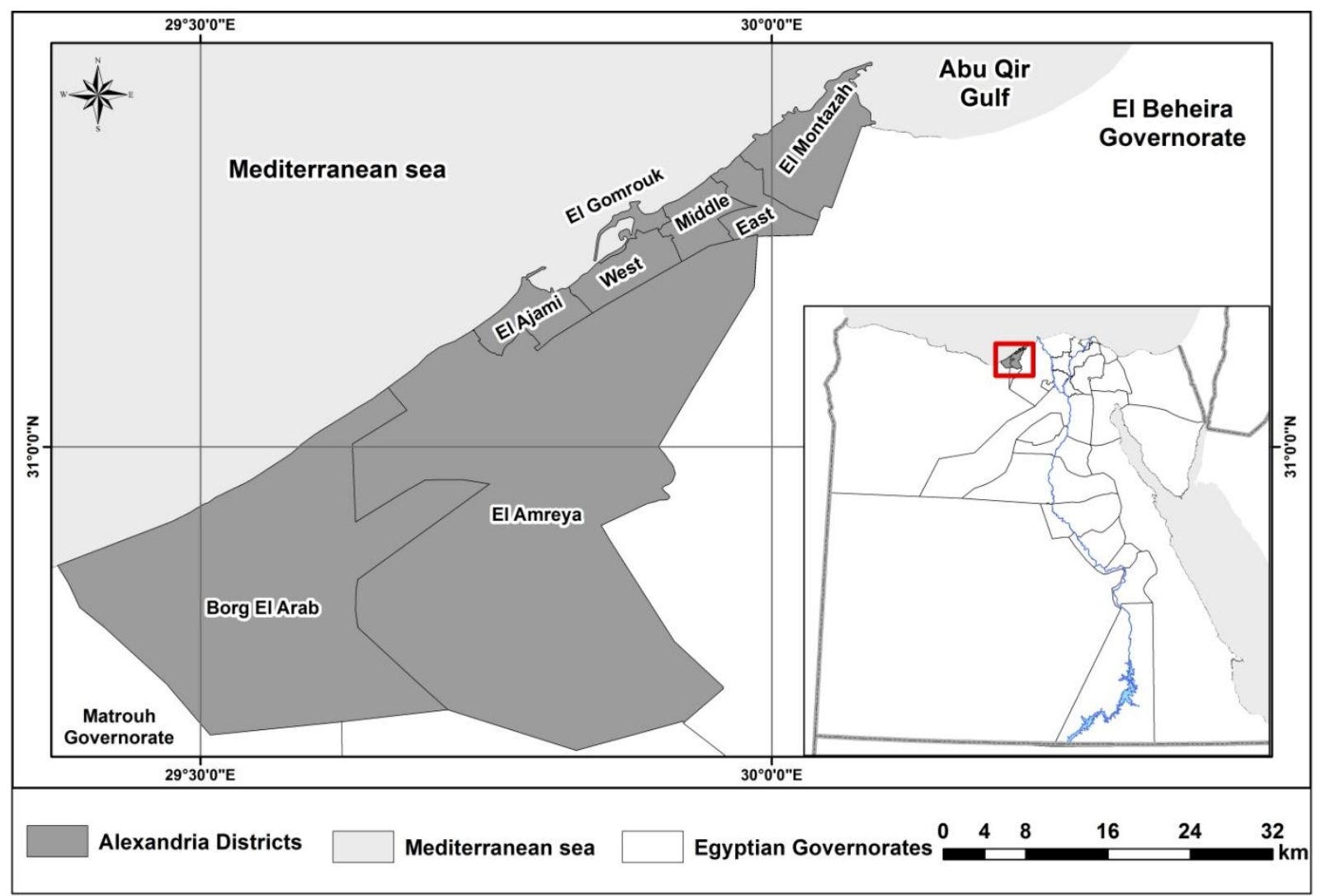

Figure 1: The Location of Alexandria governorate, and its administrative districts.

In addition, there are 3 steps to calculating the carbon footprint to Alexandria governorate. Firstly, collecting the required data which involved in the calculation process, containing (electricity consumption, natural gas consumption, Diesel, and Gasoline consumption and waste generation rate) as the yearly averages. Secondly, applying the IPCC emission factors, to calculate the GHG emission in the different units. Finally, converting the previous different units of calculation to $\mathrm{CO}_{2} \mathrm{e}$, and calculate a total carbon footprint of Alexandria governorate.

Table 1 indicates the emission factor which used in this study. The first Emission factor is about electricity $\mathrm{CO}_{2} \mathrm{e} / \mathrm{kWh}$. The second about wastes $\mathrm{CO}_{2} \mathrm{e} / \mathrm{t}$. The third is about natural and liquid gas $\mathrm{CO}_{2} \mathrm{e} / \mathrm{m}^{3}$. The fourth is about Diesel, and Gasoline $\mathrm{CO}_{2} \mathrm{e} / \mathrm{km}$. 
Table 1: Emission factor which is used in this study.

\begin{tabular}{|c|c|c|}
\hline Consumption & Emission factor & Unit \\
\hline Electricity & $0.672^{*}$ & $\mathrm{Kg} \mathrm{CO}_{2} \mathrm{e} / \mathrm{kwh}$ \\
\hline Waste & $36.808^{* *}$ & $\mathrm{Kg} \mathrm{CO} \mathrm{K}_{2} / \mathrm{Ton}$ \\
\hline Natural and liquid Gas & $0.512^{* * *}$ & $\mathrm{Kg} \mathrm{CO}_{2} \mathrm{e} / \mathrm{m}^{3}$ \\
\hline Diesel & $2.769842^{* * * * *}$ & ton $\mathrm{CO}_{2} \mathrm{e} /$ ton \\
\hline Gasoline & $2.403245^{* * * * *}$ & ton $\mathrm{CO}_{2} \mathrm{e} / \mathrm{ton}$ \\
\hline
\end{tabular}

\section{Discussion:}

The required data (electricity consumption, natural gas consumption, Diesel, and Gasoline consumption and waste generation rate) - to calculate the Carbon footprint of Alexandria governorate - was collected from the Official data sources For the period between 2010 - 2015. Table 2 indicates the calculated averages of the previous activities. Emission factors which are illustrated in Table 1 were applied to the last averages in table 3 to calculate the total emission of GHG's from the activities of consumption.

The total Carbon footprint of Alexandria governorate is 8.94 million ton $\mathrm{CO}_{2} \mathrm{e} / \mathrm{year}$ for the period between 2010-2015. The electricity sector represents the most contributor to the carbon footprint in the study area with an average of 5.6 million ton $\mathrm{CO}_{2} \mathrm{e} / \mathrm{year}$ and $62.5 \%$ of the total carbon footprint of the study area (figure 2). This is due to the fact that electricity is the major sector of consumption and related to all daily activities for the Alexandria governorate. The petroleum sector is the second contributing of the carbon footprint with an average of 2.7 million ton $\mathrm{CO}_{2} \mathrm{e} /$ year and $30 \%$ of the total carbon footprint of the study area. Natural Gas is the third contributing of the carbon footprint with an average of 0.55 million ton $\mathrm{CO}_{2} \mathrm{e} / \mathrm{year}$ and $6 \%$ of the carbon footprint in the study area. while the waste contributes less than $1 \%$ of the carbon footprint in the study area, and about 0.085 million ton $\mathrm{CO}_{2} \mathrm{e} / \mathrm{year}$. This is due to the fact that

$1 *$ IPCC special report: https://www.ipcc.ch/pdf/specialreports/sroc/Tables/t0305.pdf

** IPCC, 2006, guidelines for National Greenhouse Gas Inventories.

*** EPA https://www.epa.gov/energy/greenhouse-gases-equivalencies-calculator- calculations-and- references

**** IPCC, 1997 \& IPCC, https://www.ipcenggip.iges.or.jp/public/gp/bgp/2 3 Road Transport.pdf

****** USEPA, 2014. https://www.epa.gov/sites/production/files/2015-07/documents/emission-factors_2014.pdf 
waste is collected continuously with a rate of about $60 \%$ of the total waste, and the rest $40 \%$ is burned.

Accordingly, Housing consumption is the most common contribution of the carbon footprint in the sector of Electricity with about $52 \%$ of the total share of the sector (figure 3 ). the industrial consumption is contributing with about $19 \%$ of the sector, the commercial and facilities consumption are contributing with about 5\%, respectively of the sector. the governmental consumption is contributing with about $4 \%$, then the public use and lighting are contributing with about $1 \%$. While agriculture is contributing less than $1 \%$ of the sector.

Table 2: The calculated averages for major activities in Alexandria governorate For the period between 2010 - 2015.

\begin{tabular}{|c|c|c|}
\hline Activity of consumption & $\begin{array}{c}\text { Average of } \\
\text { consumption }\end{array}$ & Unit/year \\
\hline Electricity & $8389.41^{*}$ & million $\mathrm{kwh}$ \\
\hline Natural and liquid Gas & $1064885.5 * *$ & $\mathrm{~m}^{3}$ \\
\hline Waste & $2.309 * * *$ & million ton \\
\hline Diesel & $695710^{* * * *}$ & ton \\
\hline Gasoline & $324545^{* * * *}$ & ton \\
\hline
\end{tabular}

Table 3: The total carbon footprint of Alexandria governorate For the period between 2010 2015.

\begin{tabular}{|c|c|}
\hline Consumption & $\begin{array}{c}\text { GHG Emissions (million ton } \\
\mathbf{C O}_{2} \mathbf{e} / \text { year) }\end{array}$ \\
\hline Electricity & 5.6 \\
\hline Waste & 0.085 \\
\hline Natural and liquid Gas & 0.55 \\
\hline
\end{tabular}

$1 *$ Alexandria Electricity Company, 2016, Unpublished data.

** Egyptian Natural Gas Holding Company (EGAS), 2016, Unpublished data.

*** EEAA, 2017, Egypt State of the Environment Report 2016.

http://www.eeaa.gov.eg/portals/0/eeaaReports/SoE2017AR/Egypt-SOE-2016-FINAL.pdf

**** Egyptian General Petroleum Corporation, 2016, Unpublished data. 


\begin{tabular}{|c|c|}
\hline Diesel & 1.927 \\
\hline Gasoline & 0.779 \\
\hline Total Carbon footprint ton $\mathrm{CO}_{2} \mathrm{e}$ & $\mathbf{8 . 9 4}$ (million ton $\mathrm{CO}_{2} \mathrm{e} / \mathrm{year}$ ) \\
\hline
\end{tabular}

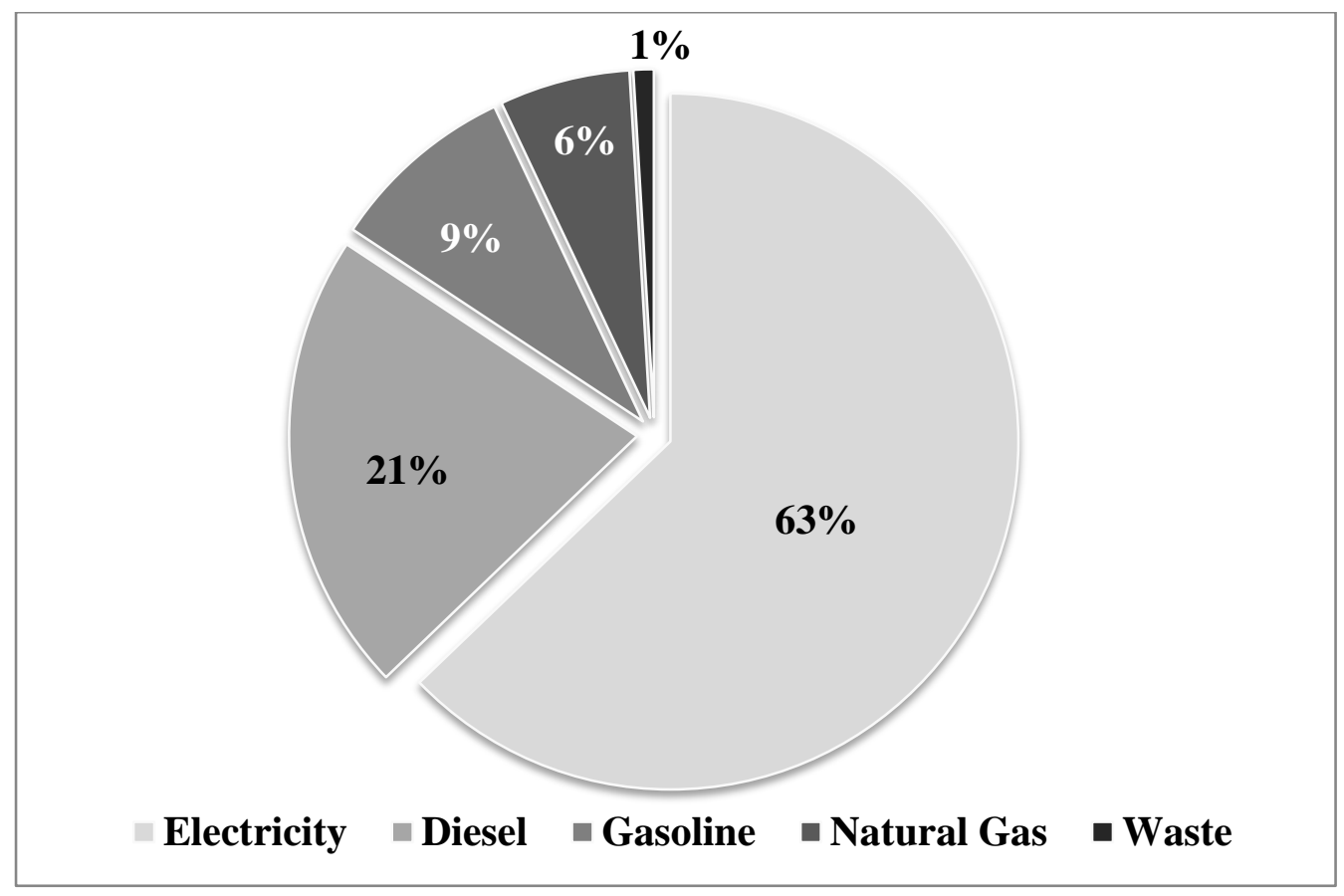

Figure 2: The percentage of contribution of different consumption sectors in the Carbon footprint 


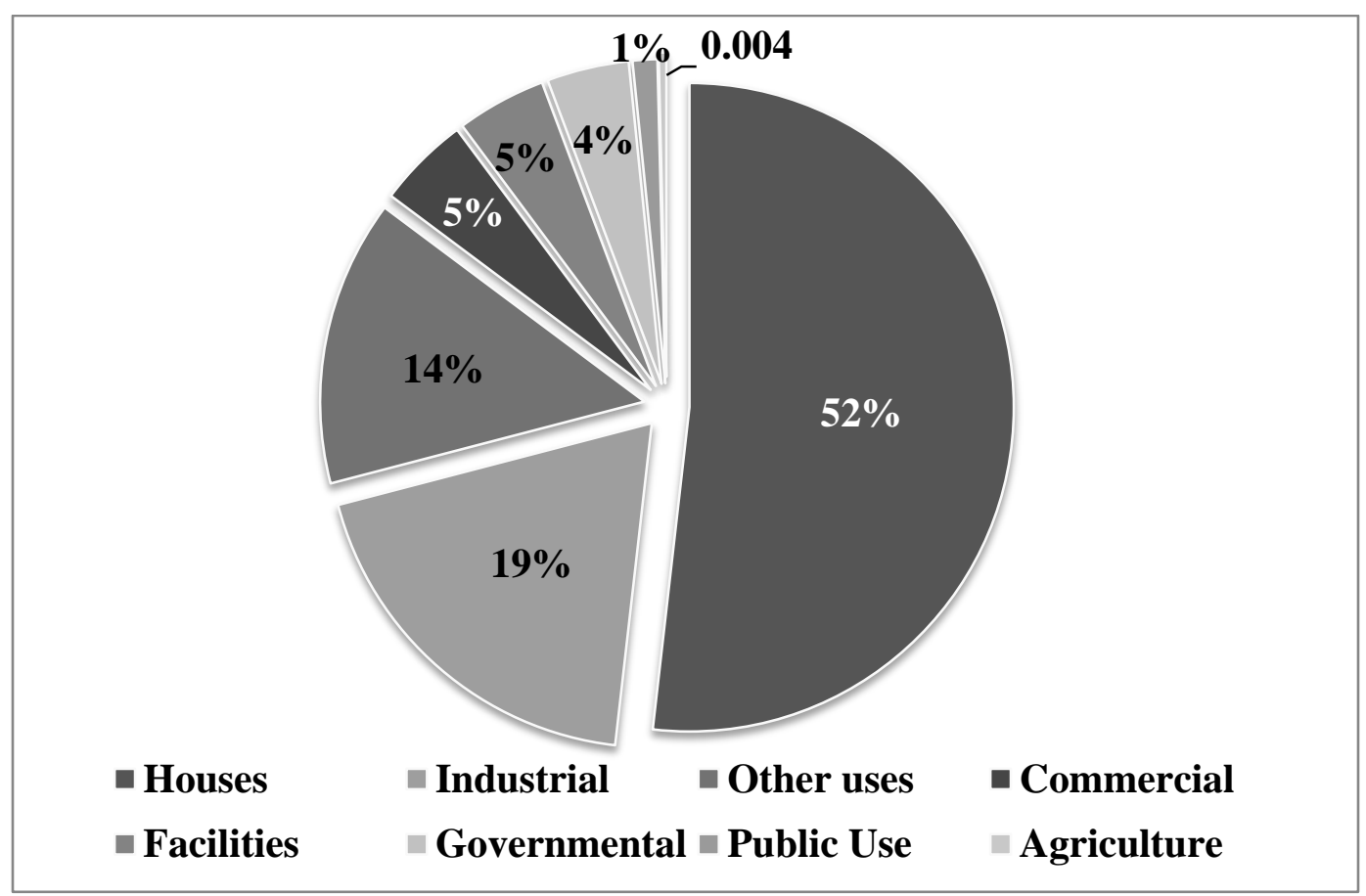

Figure 3: The percentage of contribution of different consumption sectors of Electricity in the Carbon footprint of Alexandria governorate.

Furthermore, the multi-use consumptions are the most common contribution of the carbon footprint in the sector of Natural and liquid gas with about $78 \%$ of the total share of the sector (figure 4). the industrial consumption is contributing with about $18 \%$ of the sector, housing consumption is contributing with about $3 \%$. the commercial consumption is contributing with about $1 \%$. While cars and vehicles are contributing less than $1 \%$ of the sector. 


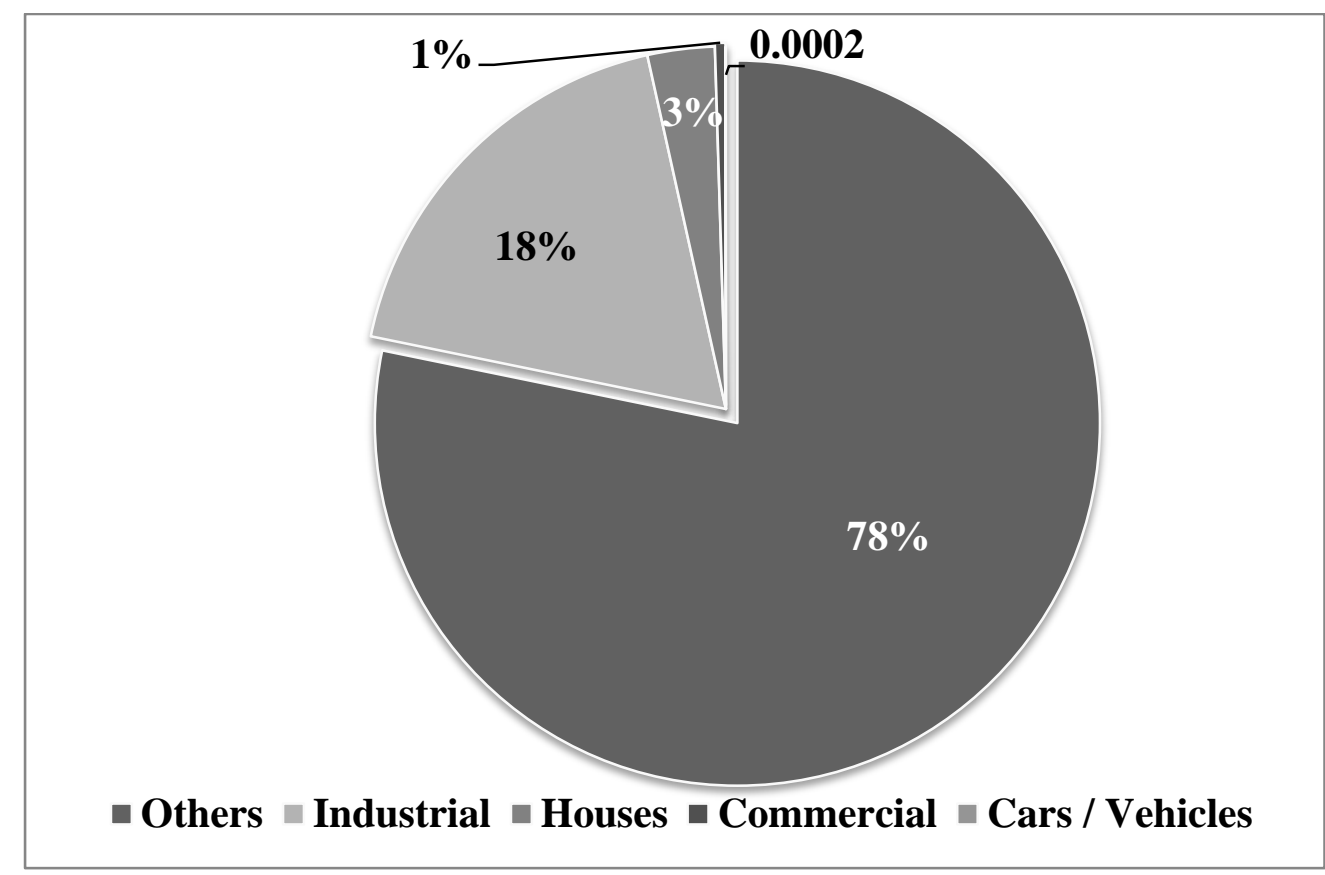

Figure 4: The percentage of contribution of different consumption sectors of Natural and Liquid Gas in the Carbon footprint of Alexandria governorate.

In addition, the spatial distribution of the carbon footprint of Alexandria governorate at the district level represent that, Middle of Alexandrian district which contains downtown, Muharram Bick, El Ibrahimia, Smouha and Abyess departments, is the most common contribution of the carbon footprint of Alexandria governorate with about 1.366 million ton $\mathrm{CO}_{2} \mathrm{e} /$ year and $15.2 \%$ of the total carbon footprint of the governorate (figures 5 and 6). East of Alexandria district which contains Saba Basha, Bacous and El Siuof departments, is the second contributing of the carbon footprint with about 1.306 million ton $\mathrm{CO}_{2} \mathrm{e} / \mathrm{year}$ and $14.5 \%$ of the total carbon footprint of the governorate. El Montazah district which contains Sidi Bishr, Abou Qir, El Mandara, El Galaa and Khorshid departments, is the third contributing of the carbon footprint with about 1.247 million ton $\mathrm{CO}_{2} \mathrm{e}$ /year and $13.89 \%$ of the total carbon footprint of the governorate. While, El Gomrouk district is the least contributing of the carbon footprint with about 0.163 million ton $\mathrm{CO}_{2} \mathrm{e} /$ year and $1.82 \%$ of the total carbon footprint of the governorate, after west of Alexandria district with about 0.199 million ton $\mathrm{CO}_{2} \mathrm{e} /$ year and $2.22 \%$ of the total carbon footprint of the governorate. Generally, the Middle and East sector of Alexandria governorate which contains Districts of El Montazah, East and Middle of Alexandria, have the most common contribution of the carbon footprint of Alexandria governorate with about 3.919 million ton $\mathrm{CO}_{2} \mathrm{e} /$ year and $43.6 \%$ of the total carbon footprint of the governorate. 


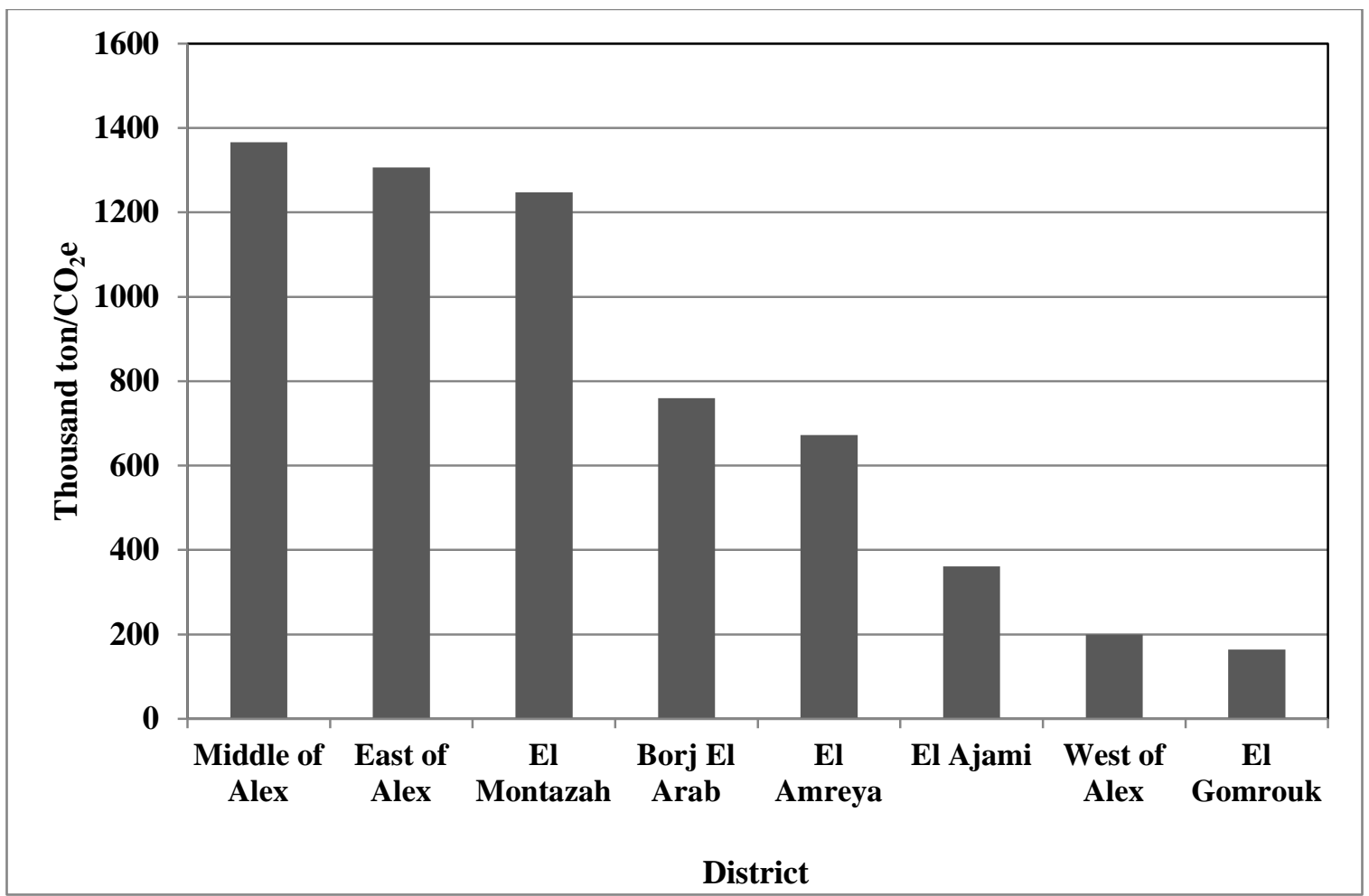

Figure 5: Contribution of Districts in the Carbon footprint of Alexandria governorate. 


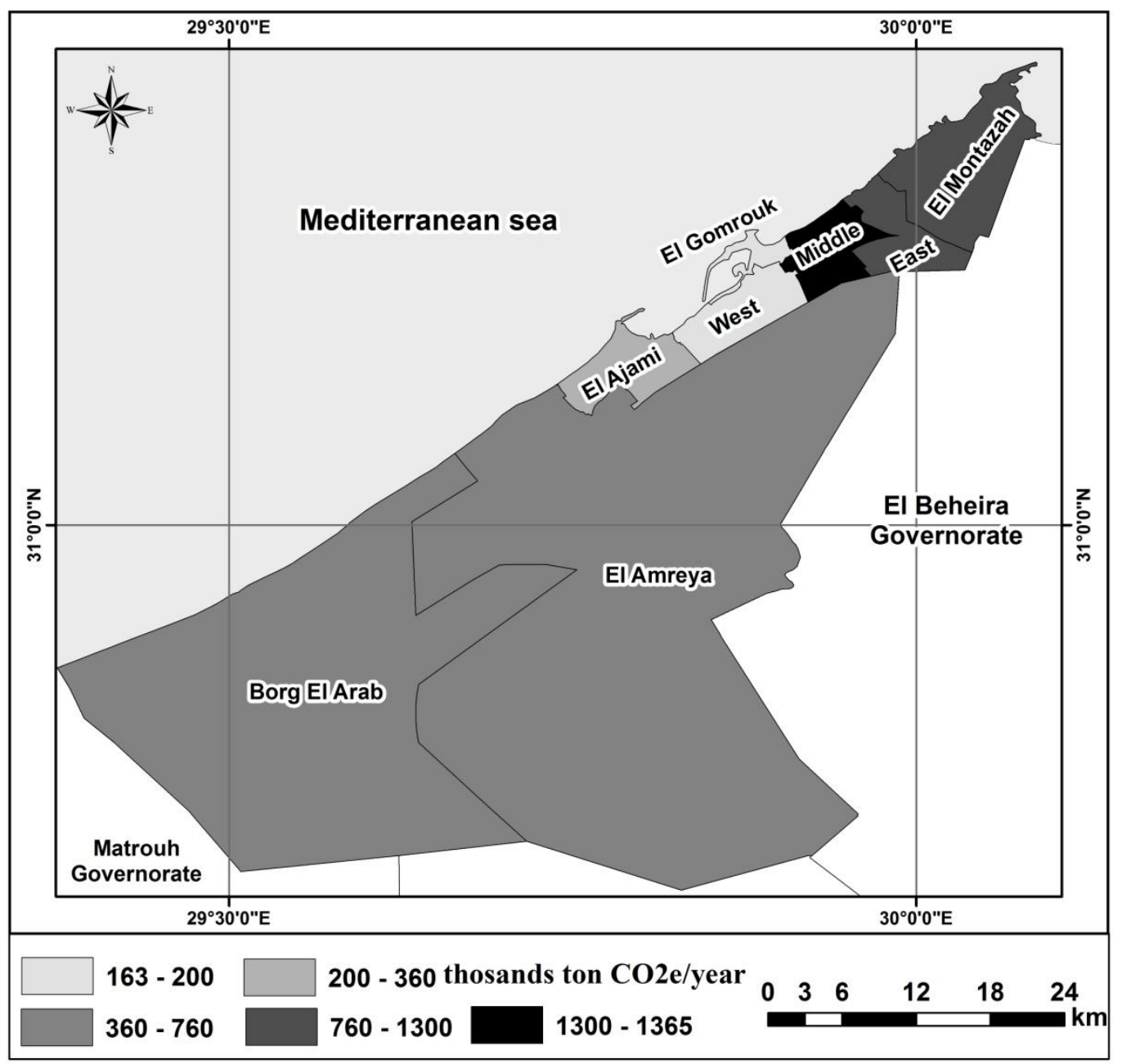

Figure 6: Spatial distribution of the Carbon footprint for Alexandria governorate.

Nevertheless, the carbon footprint of Alexandria governorate compared to some major cities in the world, such as Tokyo 2012, New York 2014, Greater Cairo 2010-2015 and London 2012. The total carbon footprint for previous cities is $69.60,49.10,12.05$ and 3.40 million ton $\mathrm{CO}_{2} \mathrm{e} /$ year, respectively (figure 7).

The commercial sector in Tokyo 2012 contributing with about 26 million ton $\mathrm{CO}_{2} \mathrm{e}$ and $37.4 \%$ of the total carbon footprint of the city. Housing sector contributing with about 20.9 million ton $\mathrm{CO}_{2} \mathrm{e}$ and $30 \%$ of the total carbon footprint of the city, and transportation sector contributing with about 12 million ton $\mathrm{CO}_{2} \mathrm{e}$ and $17 \%$ of the total carbon footprint of the city. Tokyo contributing with about $5.2 \%$ of total Japan's GHG emissions (ICAP, 2015 \& Greenhouse Gas Inventory Office of Japan, 2014 \& Climate challenges market solutions, 2015). 


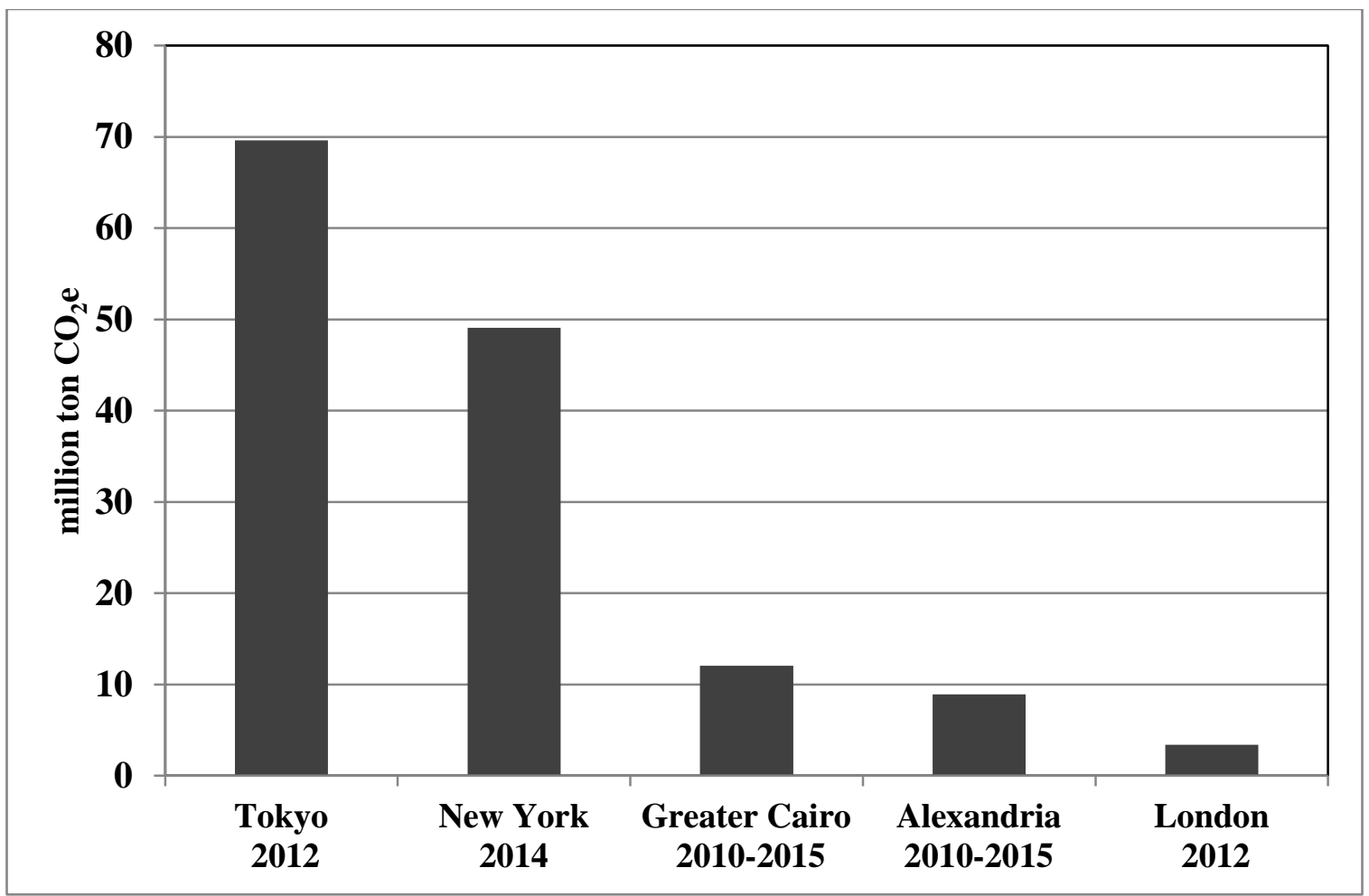

Figure 7: The carbon footprint of Alexandria governorate compared to some major cities in the world.

The Electricity sector in New York City 2014 contributing with about 30.7 million ton $\mathrm{CO}_{2} \mathrm{e}$, followed by transportation sector with about million ton $\mathrm{CO}_{2} \mathrm{e}$, hence waste sector at about 2.4 million ton $\mathrm{CO}_{2} \mathrm{e}$ (Cventure et al., 2016).

The Waste sector in Greater Cairo as average for the period of 2010-2015 has the major contribution of the total carbon footprint of the city, with about 7 million ton $\mathrm{CO}_{2} \mathrm{e}$ and $57.5 \%$ of the total carbon footprint of the city. Electrical sector contributing with about 5 million ton $\mathrm{CO}_{2} \mathrm{e}$ and $42.3 \%$ of the total carbon footprint of the city. While the petroleum and Gas sector contributing with about $0.2 \%$ of the total carbon footprint of the city. Accordingly, the carbon footprint of greater Cairo is about 5\% of the GHG emissions of Egypt (Khaled Mohamed Madkour Ali, 2018).

Housing sector in London 2012 contributing with about 21.8 thousand ton $\mathrm{CO}_{2} \mathrm{e}$ and $1.3 \%$ of the total carbon footprint of the city. Commercial sector contributing with about 1.65 million ton $\mathrm{CO}_{2} \mathrm{e}$ and $97.3 \%$ of the total carbon footprint of the city. Electricity sector contributing with about 5.6 million ton $\mathrm{CO}_{2} \mathrm{e}$ and $85.5 \%$ of the total carbon footprint of the city, Transportation sector contributing with about 194.5 thousand ton $\mathrm{CO}_{2} \mathrm{e}$ and $11.7 \%$ of the total carbon footprint of the city (Mills, 2009). 


\section{Conclusion:}

The Carbon footprint of Alexandria governorate is contributing with about $3.61 \%$ of the GHG emissions of Egypt, which was about 248 million ton/ $\mathrm{CO}_{2} \mathrm{e}$ (UNFCCC, 2016, P 28). The electricity sector is the most contributor to the carbon footprint of the study area. The Carbon footprint of Alexandria Governorate is Impacting at the climate change, and it's Equivalent to consumption of 21 million Oil barrel. In addition, needs to planting more about 230 million trees are required to be disposed of to remove the amount of greenhouse gases that have been released into the atmosphere.

\section{References:}

1. Alexandria Electricity Company, 2016, Unpublished data.

2. Alexandria Port Authority, 2018, http://www.apa.gov.eg/index.php/en

3. Alexandria governorate, 2018, http://www.alexandria.gov.eg/Government/districts/default.aspx

4. American University in Cairo (AUC), 2011, our carbon footprint, https://documents.aucegypt.edu/docs/about_sustainability/Carbon\%20Footprint $\% 202015 \% 20$ Master\%20Draft\%20v.\%206\%20FINAL.pdf

5. Calabrese, A, 2010, Navigate Latest CO2 Emissions Data by Nation and Per Capita. The State of the USA. Online: http://www.stateoftheusa.org/content/carbon-emissionsnavigator.php

6. CAPMAS, 2018, https://www.capmas.gov.eg/Pages/populationClock.aspx

7. Climate challenges market solutions, 2015, Tokyo The World's Carbon Markets: A Case Study Guide to Emissions Trading, Last Updated: May 2015.

8. Cventure, L., Pasion, C., Amar, M., Zhou, Y., 2016, City of New York Inventory of New York City's Greenhouse Gas Emissions, April 2016, Mayor's Office of Sustainability, New York, 2016.

9. Egyptian General Petroleum Corporation, 2016, Unpublished data.

10. Egyptian Natural Gas Holding Company (EGAS), 2016, Unpublished data.

11. EEAA, 2017, Egypt State of the Environment Report 2016, http://www.eeaa.gov.eg/portals/0/eeaaReports/SoE2017AR/Egypt-SOE-2016-FINAL.pdf

12. Global Warming Potentials, 2011, http://unfccc.int/ghg_data/items/3825.php. http://www.safeclimate.net/calculator/ Accessed on November 2011.

13. Greenhouse Gas Inventory Office of Japan, 2014, National Greenhouse Gas Inventory Report of Japan, April 2014, Available at: http://www-gio.nies.go.jp/aboutghg/nir/2014/NIR-JPN2014-v3.0.pdf Accessed on: 25 Apr 2016

14. ICAP, 2015, Emissions Trading Worldwide- ICAP status report, February 2015, Available at: https://icapcarbonaction.com/status-report-2015 Accessed on: 18 Sep 2016. 
15. IPCC special report: https://www.ipcc.ch/pdf/special-reports/sroc/Tables/t0305.pdf

16. IPCC, 1997, Revised 1996 IPCC guidelines for national greenhouse gas inventories, Paris: Intergovernmental Panel on Climate Change, United Nations Environment Programme, Organization for Economic Co-Operation and Development, International Energy Agency. Paris, France. http://www.ipcc-nggip.iges.or.jp/public/gl/invs1.htm

17. IPCC, Emissions: Energy, Road, Transport, Good Practice Guidance and Uncertainty Management in National Greenhouse Gas Inventories, https://www.ipccnggip.iges.or.jp/public/gp/bgp/2_3_Road_Transport.pdf

18. Khaled Mohamed Madkour Ali, 2018, Modeling air quality and GHGs in Egypt - a study in climatic geography using remote sensing and geographic information systems, $\mathrm{PhD}$ Thesis, Geography Department, faculty of arts, Ain Shams University.

19. Mills. S., 2009, City of London Carbon Footprint a Study to Determine the Carbon Footprint of the City of London, City of London Corporation, Wimbledon London SW19 4DR United Kingdom.www.urscorp.eu Accessed on: 17 Jul 2017

20. UNFCCC Egypt third national communication, 2016, http://www.eeaa.gov.eg/portals/0/eeaaReports/NCC/Egypt's\%20third\%20national\%20commu nication\%20report\%20.pdf

21. United Nations: New York, USA, 2007, City planning will determine pace of global warming, un-habitat chief tells second committee as she links urban poverty with climate change. United Nations: New York, USA, 2007; Available online: http://www.un.org/News/Press/docs/2007/gaef3190.doc.htm (accessed on 7 April 2011).

22. USEPA, 2008, Optional Emissions from Commuting, Business Travel and Product Transport, Washington DC., USA. Retrieved from http://www.epa.gov/climateleadership/documents/resources/commute_travel_product

23. USEPA, 2014. https://www.epa.gov/sites/production/files/2015-07/documents/emissionfactors 2014.pdf

24. World Bank, 2011, Middle East and North Africa. Countries. Online: http://web.worldbank.org/WBSITE/EXTERNAL/COUNTRIES/MENAEXT/0,,menuPK:247 619 pagePK:146748 piPK:146812 theSitePK:256299,00.html

25. World Resources Institute (WRI), 2011, Safe Climate, http://www.safeclimate.net/calculator/, viewed_in November 2011. 


\section{البصمة الكريونية لمحافظة الاسكندرية، مصر وأثرها في التغيرات المناخية}

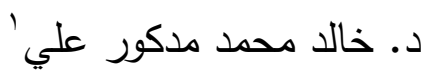

ملخص:

تهدف الدراسة إلى حساب البصمة الكربونية في محافظة الاسكندرية، وتشمل حساب انبعاثات غازات

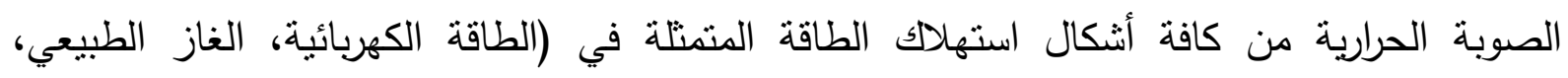

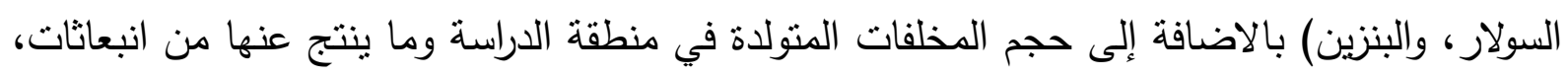

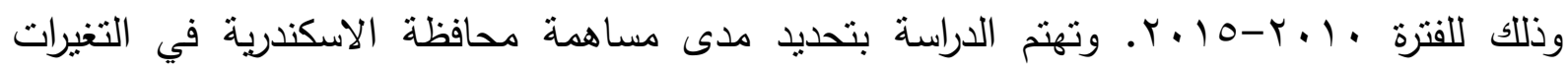

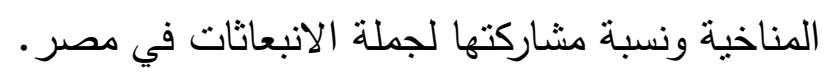

إنتهت الدراسة إلى أن إجمالي البصمة الكربونية لمحافظة الاسكندرية ييلغ ؟ ؟ 9 مليون طن ثاني أكسيد

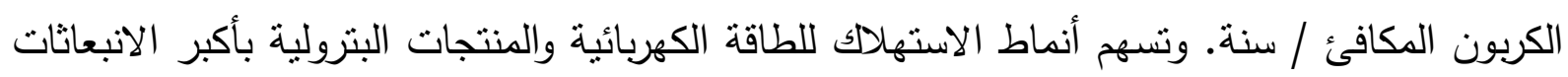

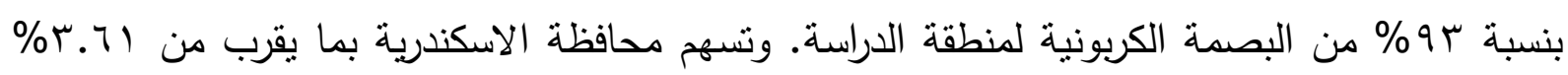

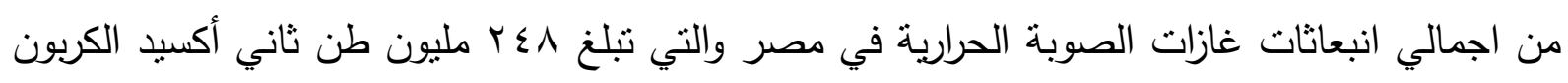
المكافئ (UNFCCC, 2016, P 28).

الكلمات المفتاحية: البصمة الكربونية، الاسكندرية، التغيرات المناخية. 